\title{
Cambridge
}

\section{The Hidden Musicians}

Music-making in an English Town

RUTH FINNEGAN

This fascinating study of local music in the modern English town of Milton Keynes documents and studies the activities of groups such as the amateur classical orchestras, church choirs, brass bands, Gilbert and Sullivan societies, and the musicians playing in the jazz, rock, folk, and country and western traditions. Ruth Finnegan's unique ethnography demonstrates the active and continuing role local part-time musicians and their supporters play in modern urban society. $£ 35.00$ net $0521360668416 \mathrm{pp}$.

\section{Now in paperback}

\section{Music and Society}

The Politics of Composition, Performance and Reception

Edited by RICHARD LEPPERT and SUSAN

\section{MCCLARY}

'Among the year's most stimulating reading material.'

Nicholas Kenyon, The Observer

'This is an important book, crowded . . . with new ideas and arguments that chalienge our assumptions.'

Musical Times

\section{Songsters and Saints}

Vocal Traditions on Race Records PAUL OLIVER

'Oliver is one of the few writers, black or white, who has made sense of perhaps the 20th century's most vibrant musical form.'

City Limits

$\therefore$. . this is almost virgin territory and Paul Oliver has made some important rediscoveries ...'

Blues Unlimited

'The range is comprehensive, the research intensive and the illustrations excellent.'

The Daily Telegraph

... a major contribution to black folklore scholarship.'

The Times Literary Supplement

$£ 30.00$ net $\mathrm{Hc} \quad 0521248272 \quad 349$ pp.

$£ 7.50$ net $\mathrm{Pb} 0521269423$

\section{The Cambridge Music Guide} Edited by STANLEY SADIE with ALISON LATHAM

This comprehensive and richly illustrated volume edited by Stanley Sadie, editor of the New Grove Dictionary of Music and Musicians, serves as an invaluable introductory guide for students and all wishing to extend their knowledge of music.

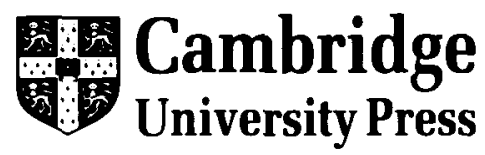

The Edinburgh Building, Cambridge CB2 2RU, UK. 


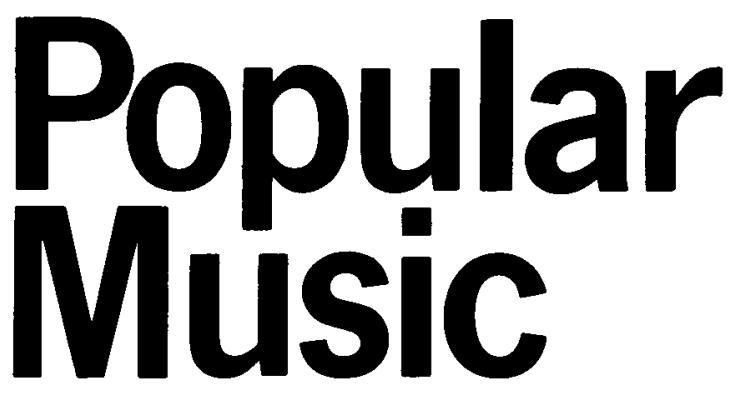

VOL. 8 NO. 1

Issue editors:

January 1989

Pages 1-130

RICHARD MIDDLETON

NORMAN JOSEPH

VOL. 8 NO. 2

Issue editors:

DAVID HORN

May 1989

Pages 131-214

DAVE LAING

VOL. 8 NO. 3

Issue editors:

October 1989

Pages 215-347

JAN FAIRLEY

STAN RIJVEN

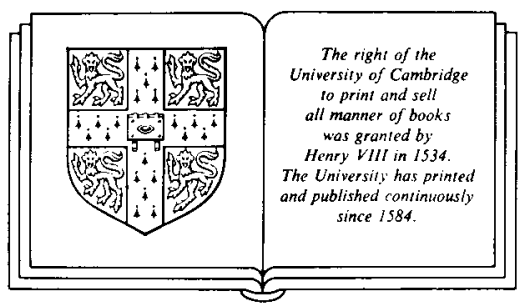

CAMBRIDGE UNIVERSITY PRESS

C A M B R I D GE

NEW YORK PORT CHESTER MELBOURNE SYDNEY 


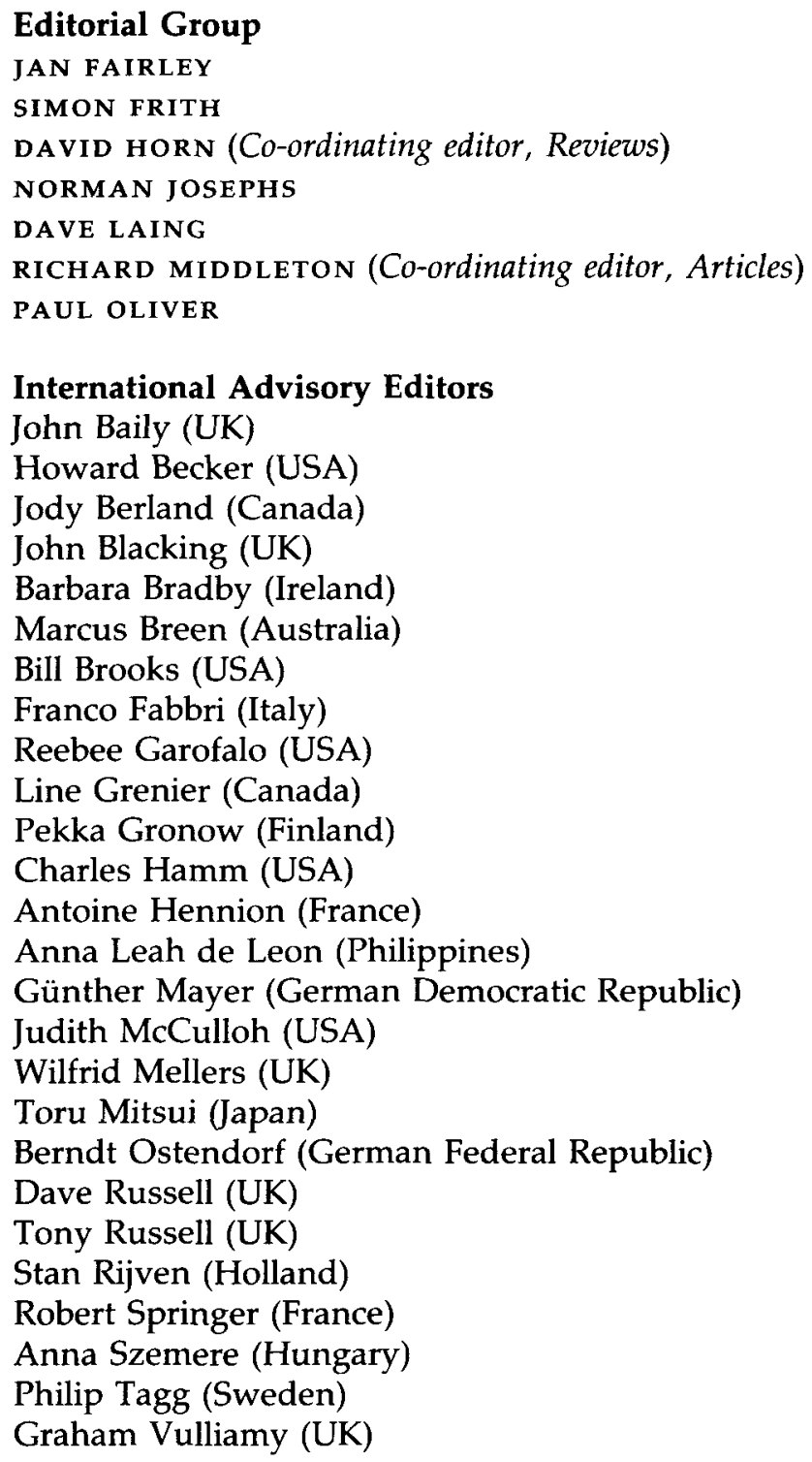

\section{Cambridge University Press}

The Pitt Building, Trumpington Street, Cambridge CB2 1RP 40 West 20th Street, New York, NY 10011, USA

10 Stamford Road, Oakleigh, Melbourne 3166, Australia

Typeset in Palatino by Wyvern Typesetting Ltd, Bristol Printed in Great Britain at the University Press, Cambridge 


\section{Contents}

JAN FAIRLEY

JOHN MOORE

SAMMIE ANN WICKS

NEIL ULLESTAD PHILIP GORDON
1 Analysing performance: narrative and ideology in concerts by ¡Karaxú!

31 'The hieroglyphics of love': the torch singers and interpretation

59 A belated salute to the 'old way' of 'snaking' the voice on its (ca) 345th birthday

Middle Eight

DAVE LAING 97 Copyright in Europe

97 CD-Video

PAUl oliver 98 Festa New Orleans: Ascona 88

SUSAN FOSTER 100 Smithsonian acquires Duke Ellington collection

JAN FAIRLEY 101 Out of the Archive and into the World of Music

SIMON FRITH 106 The John Logie Baird Centre Essay review

109 God's Gift to the Suburbs

\section{Reviews}

117 Cut'n Mix: Culture, Identity and Caribbean Music, by Dick Hebdige

120 Raising PG Kids in an X-Rated Society, by Tipper Gore

De Snider's Teenage Survival Guide or How to Be a Legend in Your Own

Lunchtime, by Dee Snider and Philip Bashe

ALAN DURANT 123 The Triumph of Vulgarity: Rock Music in the Mirror of Romanticism, by Robert

Pattison 
JOHN COLLINS 221 The early history of West African highlife music

AFOLABI ALAJA-BROWNE WERNER GRAEBNER

VEIT ERLMANN

LUCY DURAN

PHILIP TAGG

CHARLES HAMM

CHRISTOPHER BALLANTINE

STAN RIJVEN and JAN FAIRLEY

FLEMMING HARREV

RICHARD MIDDLETON

IAIN CHAMBERS

IAN WATSON

CHRIS CLARK

MICHAEL PICKERING
231 A diachronic study of change in juju music

243 Whose music? The Songs of Remmy Ongala and Orchestra Super Matimila

259 'Horses in the race course': the domestication of ingoma dancing in South Africa 1929-39

275 Key to N'Dour: the roots of the Senegalese star

285 Open letter: Black music, Afro-American music and European music

\section{Middle Eight}

299 Graceland revisited

304 A brief history of South African popular music

311 Selected discography of popular music from Africa

317 Bibliography of books on popular music in Africa

\section{Reviews}

319 Music on Deaf Ears: Musical Meaning, Ideology and Education, by Lucy Green

322 Music for Pleasure, by Simon Frith

325 Glory Days: a Biography of Bruce Springsteen, by Dave Marsh

329 Billie Holiday: Her Life and Times, by John White; Louis Armstrong: His Life and Times, by Mike Pinfold; Green Krupa: His Life and Times, by Bruce Crowther; Talking Jazz, by Max Jones

331 The Sound of History: Songs and Social Comment, by Roy Palmer

335 Booklist 
Copying: This journal is registered with the Copyright Clearance Center, 27 Congress St., Salem, Mass. 01970. Organizations in the USA who are also registered with C.C.C. may therefore copy material (beyond the limits permitted by sections 107 and 108 of US copyright law) subject to payment to C.C.C. of the per copy fee of $\$ 5.00$. This consent does not extend to multiple copying for promotional or commercial purposes. Code 0261-1430/89 \$5.00+0.00.

ISI Tear Sheet Service, 3501 Market Street, Philadelphia, Pennsylvania 19104, USA, is authorized to supply single copies of separate articles for private use only.

For all other use, permission should be sought from the Cambridge or New York offices of the Cambridge University Press.

Notes for contributors. The top (ribbon) copy of the typescript should be submitted. This must be double spaced with margins of at least $1^{\prime \prime}$. Footnotes, bibliographies, appendixes and indented quotations must also be double spaced.

Tables, graphs, diagrams and music examples must be supplied on separate sheets. illustrations should be in the form of good black and white glossy prints, ideally measuring $203 \mathrm{~mm} \times 153 \mathrm{~mm}\left(8^{\prime \prime} \times 6^{\prime \prime}\right)$. All illustrative material should be numbered and carefully keyed into the typescript. Captions should be typed double spaced on separate sheets. Contributors who wish to reproduce photographs should provide good black and white prints, full details of the source and the full address of the copyright holder if this differs. Photographs will not normally be considered unless they are an intrinsic part of the contribution and their inclusion will always be at the discretion of the editors. The full address of the copyright holder should also be provided for any other material (such as music examples/lyrics) used in which the contributor does not hold copyright.

Bibliographical material. The method of citation is author-date system (Smith 1980, p. 66), which should be given in the text rather than in footnotes; full references should be listed at the end of each article. Abbreviations for the names of periodicals, libraries etc. should not be used without explanation. For more detailed matters of style please follow the practices of A Manual of Style, 12th edn (Chicago: University of Chicago Press, 1969). 


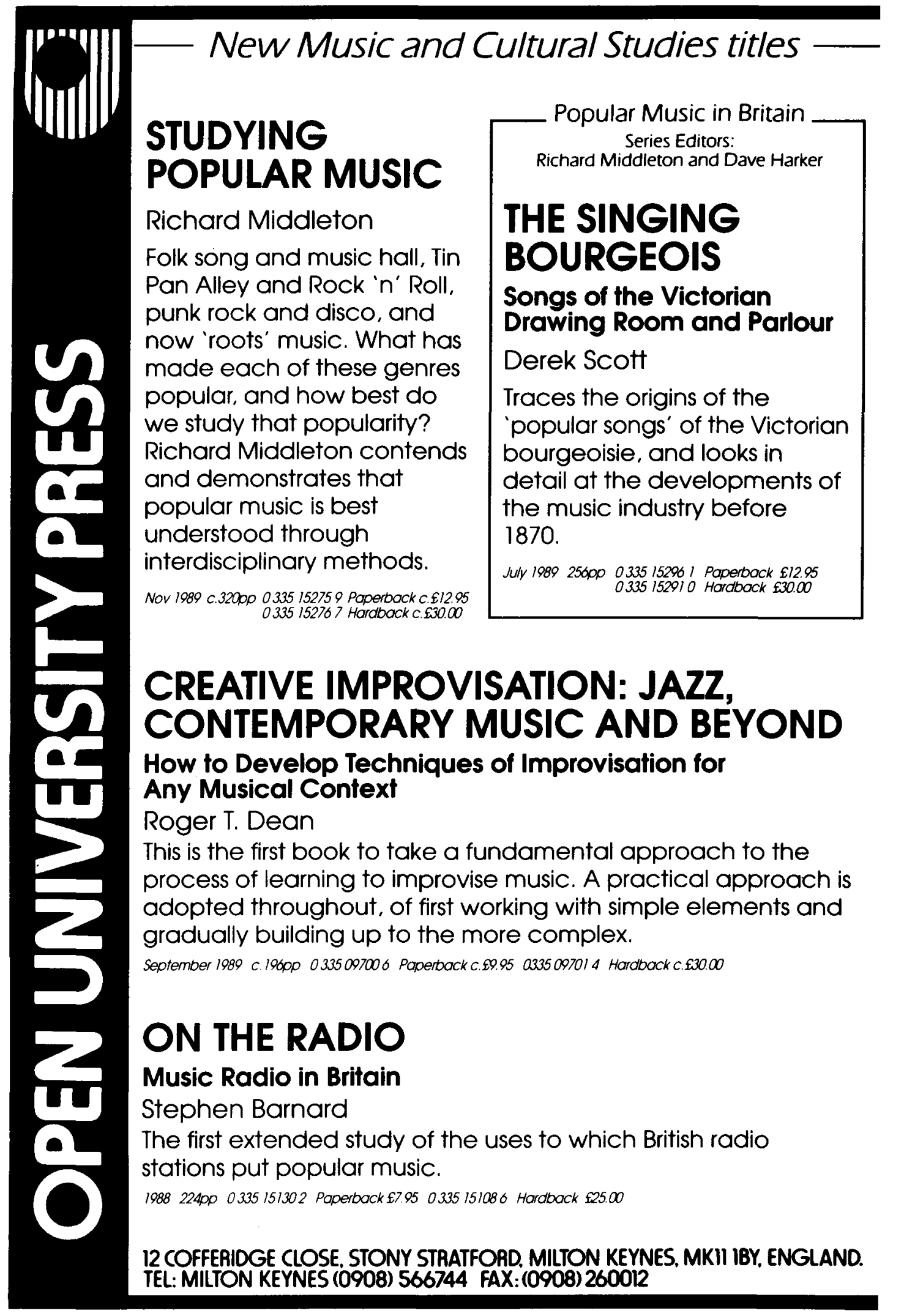

